\title{
The Effect of Service Quality, Learning Quality, and Promotion Strategy on Parents' Decisions in Choosing ABC Primary Schools
}

\author{
Soegeng Wahyoedi ${ }^{1}$, Saparso ${ }^{2}$, Melitina Tecoalu ${ }^{3}$, Hery Winoto $\mathbf{T j}^{\mathbf{4}}$ \\ Center of Innovation In Applied Management and Behavioral Economy (CIAMBE) \\ Faculty of Economics and Business, Krida Wacana Christian University, Jakarta. Indonesia \\ swahyoedi@ukrida.ac.id, saparso@ukrida.ac.id,melitina@ukrida.ac.id, hery.winoto@ukrida.ac.id
}

\section{Abstract}

To survive in the competition, educational institutions must maintain the quality both in terms of the teaching staff used and in terms of the learning provided to students. This study examines the effect of service quality, learning quality, and promotion strategies on parents' decisions in choosing primary schools for their children. Purposive sampling technique was used in the data collection process, where the respondents were the parents of students from $A B C$ primary school as many as 100 respondents. The test results show that the quality of the teaching staff, the quality of the learning methods used, and the school's promotion strategies are essential aspects that parents consider in determining the primary school for their children.
Keywords

service quality, learning quality, promotion strategy

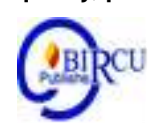

\section{Introduction}

Education at this time is an aspect that is very important for society. Particularly in Indonesia, education is a factor that has become an important spotlight for the Government in realizing one aspect of the 1945 Constitution of the Republic of Indonesia, which is stated in the market 31 paragraph (1) which states that every citizen has the right to education, and in Paragraph (3) reads that the Government shall endeavor and implement a national education system that enhances faith and piety as well as noble morals in the framework of the intellectual life of the nation. To advance education in Indonesia, the Government has implemented the Nine Year Compulsory Education program as stated in the Government Regulation of the Republic of Indonesia No. 47 of 2008. This program requires every child in Indonesia to study at formal educational institutions from primary school to junior high school. Through the implementation of this program, it has increased public demand for formal education institutions, both state-owned and private.

The increasing number of schools at various levels of education that have been established in Indonesia shows the increasing competition in the world of education. This competition makes each school compete with each other in highlighting the quality of education it offers prospective students. In school selection, especially at the primary school level, parents will have many factors to consider, such as the quality of learning provided by the school and the quality of the teachers at the school. Of course, parents want their children to get a good and adequate education from the best schools. Primary school is the level of initial education taken by students, where in addition to being provided with education, they will also be taught and instilled aspects of morality that are useful for the development of children's character. Parents in determining the school for their children must consider several important factors, such as the quality of the learning provided by the teacher, the curriculum used, the facilities, and the school environment. 
In today's competitive environment, it is very important for primary schools to implement the marketing mix and the quality of teaching from teachers to students because a combination of good marketing mix strategies and obtaining competent teaching staff can attract the attention of parents in determining the school for their child. For this reason, this study will examine the effect of service quality and marketing mix on parents' decisions in choosing $\mathrm{ABC}$ primary schools for children.

Service is a series of intangible activities where in the process, there is an interaction between the recipient and the service provider with the aim of providing the resources and solutions needed by the service recipient (Fitzsimmons \& Fitzsimmons, 2006: 4). Parasuraman et al. (1985: 41) classifies three characteristics of services, including intangibility where services cannot be measured, calculated, inventoried before being sold to ensure quality, heterogeneity where the performance provided by service providers can be different to each service recipient, inseparability where production and consumption of services cannot be separated.

Service quality and innovation are two elements that can build competitive advantage, because the quality of service as a infrastructure that is adequate in providing services, while innovation is applied because consumers want a renewal in the services perceived by consumers, so the end result of service quality and innovation is the creation of competitive advantage (Kusumadewi and Karyono, 2019). Meanwhile Kurnaedi et al (2020) stated that Service quality is a form of performance that is identical to the behavior of employees in the company. Behavior of these employees in the company can be influenced by climate and organizational culture.

Service quality is a difference between the perceptions of consumers who get the services provided and compared with the expectations of consumers (Parasuraman et al., 2001). Service quality is something that meets the expectations of consumers, and when consumer expectations are achieved, consumers can become loyal to these services (Wahyoedi and Winoto 2018). Good quality occurs when the services received by comparable consumers can even exceed the expectations of consumers for the services received. There are five dimensions to service quality:

1. Tangibles: It is the physical facilities, as well as the appearance of the service provider.

2. Empathy: This is the care and attention given by service providers to consumers.

3. Reliability: This is the ability to provide the promised services accurately and consistently.

4. Responsiveness: It is the desire to provide assistance to consumers and the responsiveness of service providers.

5. Assurance: This is the expertise, knowledge, and abilities possessed by service providers in realizing consumer trust and confidence.

Moogan (2011: 574) explains that the essence of marketing in educational institutions is the promise of customer service and value offered to students, where students gain knowledge and can develop their skills. This aspect also applies in primary school marketing, where schools offer value to parents where their children will acquire knowledge, develop skills, and enhance their personalities. Marketing strategies can be developed to attract appropriate students, where the practice of communicants is tailored to the information needs of potential students.

Wirtz et al. (2013: 20) explain that in developing ways to market a product, marketers must have a focus on four important aspects, namely product, price, place or distribution channel, and promotion. This aspect is known as "4P" or marketing mix. However, a school is an institution that offers not only a product in the form of a learning curriculum, facilities, and the environment but also offers service aspects in the form of the 
quality of teaching staff. Therefore, the term 7P is known, which is an aspect of the marketing mix that also combines the service factor in it. Enache (2012: 25) states that the $7 \mathrm{P}$ aspect greatly determines the preferences of potential customers in determining their choices.

Ivy (2008: 289) explains that the school curriculum must be developed appropriately and adapted to the needs of students and educational development. This is, of course, important for the cultivation and development of education of students who take early education at the primary school level. In addition, prices in the context of education costs also play an important role. Enache (2011: 26) explains that the cost of education is influenced by demand, competitor prices, and the quality that schools provide to students. The price element not only affects the income of the educational institution from the applicants but can also influence students' perceptions of the quality provided. A higher cost of an educational program can indicate a better educational institution, or that the program offered by the educational institution is new or rare in the market (Enache, 2011: 26). In addition, in the competitive era in the face of competition, promotion strategies are of course also important to attract the attention of parents in choosing schools for children. Promotion can be done in the form of special prices, discounts, or other soft selling provided by the school. On the other hand, a place in a context such as the facilities and environment provided by the school to its students is a reflection of students' perceptions of the quality of the school. Various tangible aspects will be one of the crucial aspects for potential target consumers in determining which school to choose.

Research problem formulation:

1. Does service quality significantly affect parents' decisions in choosing $A B C$ primary schools?

2. Does the quality of learning significantly influence parents' decisions in choosing $A B C$ primary schools?

3. Does the promotion strategy significantly influence parents' decisions in choosing $A B C$ primary schools?

\section{Research Conceptual Model}

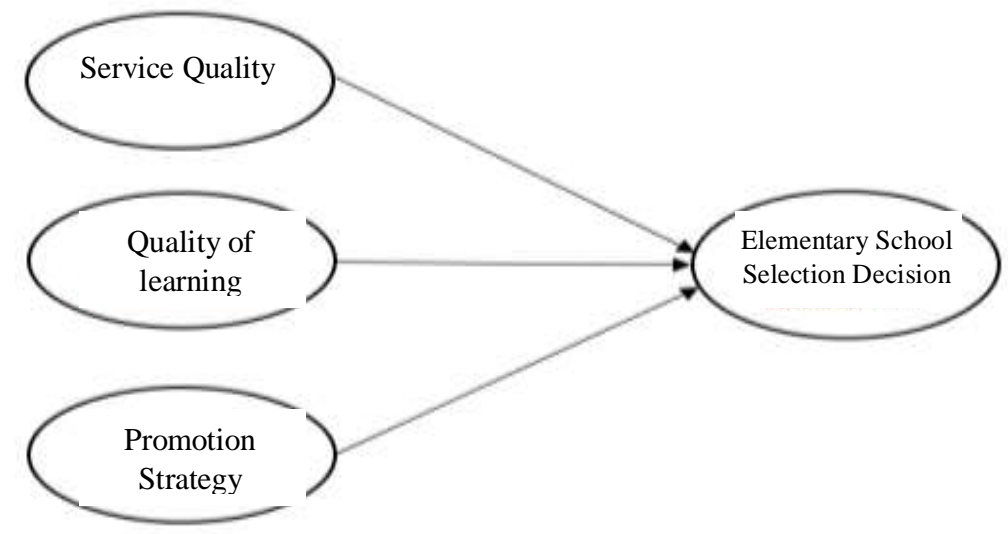

Figure 1. Conceptual Model

H1: Service Quality has a significant effect on parents' decisions in choosing ABC primary schools.

$\mathrm{H} 2$ : The quality of learning has a significant effect on parents' decisions in choosing $\mathrm{ABC}$ primary schools.

H3: Promotion strategy has a significant effect on parents' decisions in choosing ABC primary schools. 


\section{Research Methods}

The population in this study were the parents of ABC Primary School students in the South Tangerang area. Sampling using non-probability sampling technique, namely purposive sampling. The samples taken were 100 students' parents. Data collection was carried out through a questionnaire instrument, which was given directly to the respondents. Data analysis used linear regression through SPSS.

\section{Discussion}

The first step in conducting data analysis is to test the validity and reliability of the indicators and variables in the study. The validity test of the indicators aims to show that each statement indicator of each variable is able to explain the variable under study (variable Y), or it can be said to be the right measurement.

Table 1. Validity Test

\begin{tabular}{|c|c|c|c|c|c|c|c|}
\hline Indikator: & $\begin{array}{c}\text { Corrected } \\
\text { Item-Total } \\
\text { Correlation: }\end{array}$ & Indikator: & $\begin{array}{c}\text { Corrected } \\
\text { Item-Total } \\
\text { Correlation: }\end{array}$ & Indikator: & $\begin{array}{c}\text { Corrected } \\
\text { Item-Total } \\
\text { Correlation: }\end{array}$ & Indikator: & $\begin{array}{c}\text { Corrected } \\
\text { Item-Total } \\
\text { Correlation: }\end{array}$ \\
\hline SQ1 & (0,582 & KP1 & "0,604 & SP1 & "0,427 & $\overline{\mathrm{K} \text { K1 }}$ & 0,722 \\
\hline SQ2 & 0,503 & KP2 & 0,724 & SP2 & 0,508 & K2 & 0,659 \\
\hline SQ3 & 0,352 & KP3 & 0,620 & SP3 & 0,506 & K3 & 0,607 \\
\hline SQ4 & 0,487 & KP4 & 0,416 & SP4 & 0,548 & K4 & 0,619 \\
\hline SQ5 & 0,453 & KP5 & 0,672 & SP5 & 0,701 & K5 & 0,537 \\
\hline
\end{tabular}

Source: Processed by Researcher

Testing the validity of all research variable indicators in the results above shows that the value of the corrected item-total correlation exceeds 0.30 (Ghozali, 2007). So it can be concluded that all indicators are valid.

Table 2. Reliability Test

\begin{tabular}{cc}
\hline \hline Variabel : & Cronbach's Alpha: \\
\hline \hline Service Quality & 0,821 \\
Kualitas Pembelajaran & 0,887 \\
Strategi Promosi & 0,825 \\
Keputusan Pemilihan & 0,801 \\
Sekolah & \\
\hline \hline
\end{tabular}

Source: Processed by Researcher

The purpose of this test is to measure the consistency of measurement data in the study. The table explains that Cronbach's alpha value for all variables is higher than 0.60. So it can be concluded that all constructs in this study are reliable (consistent).

Table 3. Normality Test

\begin{tabular}{ccc}
\hline \hline & $\begin{array}{l}\text { Kolmogorov- } \\
\text { Smirnov Test }\end{array}$ & Saphiro-Wilk Test \\
\hline \hline Sig. & 0,137 & 0,369 \\
\hline \hline & \multicolumn{2}{c}{ Source: Processed by Researcher }
\end{tabular}


This test aims to see the data distribution or data distribution as a whole in this study. The data distribution must meet the normal distribution rules. The significance value resulting from the Kolmogorov-Smirnov (0.137) and Saphiro-Wilk (0.369) test exceeds the significant level in this study, namely $5 \%$. So it is said that the data in this study have met the normal distribution rules.

Table 4. Multicolonearity Test

\begin{tabular}{ccc}
\hline \hline & \multicolumn{2}{c}{ Collinearity Statistics } \\
\cline { 2 - 3 } & Tolerance Value & VIF Value \\
\hline \hline Service Quality & 0,602 & 1,075 \\
Kualitas & 0,602 & 1,075 \\
Pembelajaran & 0,602 & 1,075 \\
Strategi Promosi & 0
\end{tabular}

Source: Processed by Researcher

This test aims to detect a high correlation between the independent variables in the research model. Multicollinearity problems occur when the results of this test indicate a high correlation, which can be detected through tolerance and VIF values. The test results are shown through the tolerance value $(\geq 0,1)$ and Variance Inflation Factor (VIF) $(\leq 10)$, which can be seen in the collinearity statistics column. Based on the table above, it is concluded that there is no multicollinearity problem of data in this research model.

Table 5. R-Square

\begin{tabular}{cc}
\hline \hline \multicolumn{2}{c|}{ Model Summary } \\
\hline \hline $\mathrm{R}$ & 0,745 \\
R-Square & 0,562 \\
Adjusted R-Square & 0,547 \\
\hline Source: Processed by Researcher
\end{tabular}

The R-Square of 0.562 , which is $56.2 \%$, means that service quality, learning quality, and promotion strategies have a fairly substantial predictive level in explaining the decision to choose primary schools, namely $56.2 \%$.

Table 6. Hypothesis Test

\begin{tabular}{ccc}
\hline \hline & Koefisien & Sig. \\
\hline \hline Service Quality & 0,380 & 0,000 \\
Kualitas Pembelajaran & 0,332 & 0,023 \\
Strategi Promosi & 0,211 & 0,018 \\
\hline \hline
\end{tabular}

Source: Processed by Researcher

Through the results of testing the hypothesis in this study:

1. The first result shows the significant value of service quality of 0.000 , and the coefficient value obtained is positive at 0.380 . So that hypothesis 1 is proven that service quality has a significant positive effect on parents' decisions in choosing $A B C$ primary schools for children. The better the quality of the teachers given to students, the more it will be a good consideration for parents in choosing schools for their children.

2. The second result shows a significance value of 0.023 (learning quality) with a coefficient of 0.332 . It is proven that the second hypothesis is supported by data, which 
shows that the quality of learning has a significant positive effect on parents' decisions in choosing $\mathrm{ABC}$ primary schools for children. A good curriculum design that is tailored to the needs and development of education makes the quality of education provided by schools an advantage that can have an impact on parents' interest in choosing schools for children.

3. The third result shows a positive $(0.211)$ and significant $(0.018)$ value, which shows that the promotion strategy has a significant positive effect on parents' decisions in choosing $\mathrm{ABC}$ primary schools for children. The promotion strategy carried out by schools in attracting parents' attention is also an important supporting factor, where the more attractive the promotion offered by the school, the more it will attract the attention of parents in choosing schools for their children.

\section{Conclusion}

This study aims to examine the effect of service quality, learning quality, and promotion strategies on parents' decisions in choosing $\mathrm{ABC}$ primary schools for children. Through the test results obtained, it can be concluded that the three hypotheses in this study are supported where:

1. Service quality has a significant positive effect on parents' decisions in choosing $A B C$ primary schools for children. The better the quality of the teachers given to students, the more it will be a good consideration for parents in choosing schools for their children.

2. The quality of learning has a significant positive effect on parents' decisions in choosing ABC primary schools for children. A good curriculum design that is tailored to the needs and development of education makes the quality of education provided by schools an advantage that can have an impact on parents' interest in choosing schools for children.

3. The promotion strategy has a significant positive effect on parents' decisions in choosing $\mathrm{ABC}$ primary schools for their children. The promotion strategy carried out by schools in attracting parents' attention is also an important supporting factor, where the more attractive the promotion offered by the school, the more it will attract the attention of parents in choosing schools for their children.

\section{References}

Enache, Ioan - Constantin. Marketing Higher Education Using the 7 Ps Framework. 2011. Bulleting of the Transilvania University of Brasov. Volume 4 (53). Number 1. Page: $24-30$.

Fitzsimmons, James A., and Fitzsimmons, Mona J. 2006. Service Management: Operations, Strategy, Information Technology. International Edition. McGraw- Hill.

Ghozali, Imam. 2007, Aplikasi Analisis Multivariate Dengan Program SPSS, Universitas Diponogoro, Semarang.

Iskandar, Irfan Saputra, and Soegeng Dan Price Perception." 8(1):18-25.

Ivy, Jonathan. 2008. A New Higher Education Marketing Mix: the 7 Ps for MBA Marketing. International Journal of Educational Management. Volume 22. Number 4. Page: $288-299$. 
Kusumadewi, R.N., and Karyono, O. (2019). Impact of Service Quality and Service Innovations on Competitive Advantage in Retailing. Budapest International Research and Critics Institute-Journal (BIRCI-Journal). P. 366-374.

Kurnaedi, E., et al. (2020). Strategy for Improving Service Performance through Organizational Culture and Climate. Budapest International Research and Critics Institute-Journal (BIRCI-Journal). P. 1360-1368.

Moogan, Yvonne J. 2011. Can a Higher Education Institution's Marketing Strategy Improve the Student Institution Match? 2011. International Journal of Educational Management. Volume 25. Number 6. Page: 570 - 589.

Parasuraman, A.; Zeithaml, Valarie A. and Berry, Leonard L. 1985. A Conceptual Model of Service Quality and Its Implications for Future Research. Journal of Marketing. Volume 49. Page: $41-50$.

Parasuraman, A., Grewal, Dhruv, and Krishnan, R. 2007. Marketing Research. Second Edition. Houghton Mifflin.

Puteri, T., and H. Tj. 2016. "Pengaruh Pendidikan Dan Pelatihan Kerja Serta Lingkungan Kerja Terhadap Kinerja Karyawan Pt Inplasco Prima Surya.” Jurnal Ilmiah Manajemen Bisnis Ukrida 16(1):96853.

Tj, Hery Winoto. 2020. "Pengaruh Kualitas Produk dan Harga terhadap Keputusan Pembelian Minuman Bobba yang Dimediasi dengan Strategi Promosi." Jurnal Ilmiah Indonesia.

Tj, Hery Winoto, and Hans Harischandra Tanuraharjo. 2020. "The Effect Of Online Learning Service Quality On Student Satisfaction During COVID19 Pandemic In 2020." Jurnal Manajemen Indonesia 20(3):240. doi: $\quad 10.25124 /$ jmi.v20i3.3520.

Wahyoedi, Soegeng, and Hery Winoto. 2018. "Pengaruh Religitas, Kualitas Layanan Dan Trust Terhadap Loyalitas Nasabah Bank Syariah Di Kota Bogor.” Jurnal Riset Ekonomi Dan Manajemen 17 (2): https://doi.org/10.17970/jrem.17.17 0204.id.

Wiflihani, Marantika, J. E. R., Tj, H. W., Hendrawan, $\quad$ D., Azhar, P. C., \& Mohzana. (2020). The organization and management of the national education system. European Journal of Molecular and Clinical Medicine, $\quad 7(2)$.

Wirtz, Jochen; Chew, Patricia, and Lovelock, Christopher. 2013. Essentials of Services Marketing. Second Edition. Pearson. 